questionable creative value, of dissipation of staff effort in administration, and of dependence upon unreliable short-range financial support. The committee recommended that greater emphasis be given to periodic and realistic evaluations of all aspects of sponsored research in relation to the educational programme.

It was also appreciated that social trends towards a broader base of higher education and financial trends toward decreased endowment incomes pose problems for the Institute no less than for other private institutions, and that, in future, the primary goal of private institutions should be to provide limited groups with useful kinds of education not readily duplicated elsewhere. It is recommended, therefore, that the Institute limits its educational efforts to fields in which it clearly excels and that it should continue to give special emphasis to the pioneering of new ventures in which its leadership could be of distinct value to the community and the nation. The four fields of engineering, science, architecture and planning, and the humanities and social sciences, would be the most appropriate for education and research at the Institute, and the committee believes that the Institute is now in a position to make outstanding contributions to education and the advancement of knowledge in each of these four fields. A general strengthening of the school structure is recommended.

The report also contains details of recommendations and syllabuses drawn up by a committee on general education, as well as proposals for strengthening the physical and intellectual environment of the staff and the Institute.

\section{SOCIAL SCIENCE RESEARCH IN SARAWAK}

A

RECENT report by Dr. E. R. Leach on "Social Science Research in Sarawak"* is the outcome of a short preliminary study undertaken to prepare the way for a more comprehensive and penetrating "Social-Economic Survey of Sarawak", which, too, is to be sponsored by the Colonial Social Science Research Council. Although the main objective of this short report is stated to be to determine "the requirements of scientific staff and finance", much more attention has been quite rightly paid to a general reconnaissance of the physical and human resources of the territory, and the problems which appear most tempting to the social anthropologist. A programme of work is outlined as a result, which is of interest both to the administrator 'on the spot', who is necessarily absorbed in day-to-day affairs, and to the anthropologist, whose primary interest is the advancement of his science. It is to be hoped that it will be implemented without delay.

The projects contained in this programme are undoubtedly of much theoretical interest. A fair sample is the Melanau Sago Project, under which it is proposed to study a community engaged on the production of sago by traditional methods ; this is to be extended to include the study of the process of social transition from pagan to Moslem organization, and the changes in class structure resulting from modern * Colonial Office. Colonial Research Studies, No. 1 : Social Science
Research in Sarawak; a Report on the Possibilities of a Social Economic Survey of Sarawak presented to the Colonial Social Science Research Council. By Dr. E. R. Leach. Pp. ii +93. (London: H.M. Stationery Office, 1950.) 8s. 6d. net. political and economic conditions in a traditionally class-stratified society. The project is therefore both comprehensive and penetrating; the scientific interest is plainly apparent; and its utility is evident from the fact that it will throw light on the producers' end of the Chinese trade and marketing organization, and on the influence of Christian missions on the relations between pagans and Moslems in Melanau society.

The pity of it is that all this work was not done thirty years ago, when the political and social climate was much more favourable and the time-factor was not of the overwhelming importance that it has assumed to-day. Leisurely study of the 'native' is surely something that will prove to be much more typical of the first half of the twentieth century than the second. Our contemporary world is overshadowed by the political consequences of the rise of nationalism in all the under-developed territories, and the social consequences of the rapid growth of population in them. These problems appear as living issues at many points in the report; it must be regretted that the author did not consider himself to be more directly concerned with thern. None of the research projects has a sufficiently close bearing on them to justify the expectation that they can be relied on to any great extent to assist in their solution at any time in the near future. Such "purely political" matters as sedition "hardly concern" the author; changes in the attitudes and ways of life of European residents in Sarawak are considered to be "plainly quite outside the scope" of the report. This conclusion ignores the fact that it is the relationship between the peoples of Sarawak and the outside world which is the most critical factor in their social lives to-day; the rigid limits which the author has placed on his responsibilities and his interests can only be regarded as a cause for concern. The time is now long past when it first became evident that the disruptive forces latent in all Colonial societies must be brought under control, and that ways and means of understanding them must be discovered before this can be done. The pace of political and social change is steadily quickening, and a new note of urgency is required in reports of this kind.

\section{EDUCATION AND TRAINING OF ELECTRICAL TECHNICIANS}

A $\mathrm{T}$ the ordinary meeting of the Institution of A Electrical Engineers, held on November 2, 1950, Sir Arthur Fleming presented a report entitled "The Education and Training of Electrical Technicians"*. This report is the work of a joint committee set up by the British Electrical and Allied Manufacturers' Association, the Council of the Institution of Electrical Engineers, and the Radio Industry Council.

It will be recalled that the Institution of Electrical Engineers has already published reports dealing with the education and training of professional electrical engineers. In these earlier reports mention was made of the special needs of the members of an important section of the technical personnel of the electrical industry who, for purposes of classification, had been termed technicians. The present report attempts to specify the nature and scope of the activities of the technician and puts forward recommendations for his theoretical and practical training.

* The Education and Training of Electrical Technicians. Pn 32. (London: Institution of Electrical Engineers, 1950.) 18. 